\title{
Use of Suitable Fungicides for the Control of Gummosis Caused By (Phytophthora sp.) on Nagpur Mandarin in Satpura Plateau of Madhya Pradesh, India
}

\author{
Bhupendra Thakre ${ }^{1 *}$, Uttam Soni $^{2}$ and C.L. Gour ${ }^{1}$ \\ ${ }^{1}$ Department of Plant Pathology, ${ }^{2}$ Department of Agronomy, Zonal Agricultural Research \\ Station, JNKVV, Chhindwara, MP 480001, India \\ *Corresponding author
}

\section{A B S T R A C T}

Phytophthora sp. cause the most serious and economically important soil borne

Keywords

Citrus, Nagpur

Mandarin,

Gummosis,

Phytophthora sp.,

Fungicide,

Bordeaux paste.

Article Info

Accepted:

26 June 2017

Available Online:

10 July 2017

disease of citrus in Madhya Pradesh, India. They are the most damaging soil borne fungi that attack citrus plant at any age. Gummosis (Phytophthora sp.) of citrus is major problem in citrus orchards worldwide. Very little is known about the incidence and importance of Gummosis on bearing citrus tree. Measures for controlling citrus trunk lesions caused by Phytophthora sp. are largely preventive. When infection does occur, application of a fungicide to the infection site after removal of the bark is the recommended treatment. Fungicide treatment for control of Gummosis (Phytophthora sp.) was made 10 - 12 year age Nagpur Mandarin orchard at Sausar block of chhindwara district of Madhya Pradesh in year 2014-15 with study object Use of suitable fungicide for the control of gummosis caused by (Phytophthora sp.). Study indicates that Development of the lesion stared from September. Inhibition in the development of lesion was recorded as compared to check where no paste was used. Bordeaux paste 1.0 percent amended with mustard oil was most effective.

\section{Introduction}

Phytophthora spp. causes the most important soil and water-borne diseases of citrus these pathogens are worldwide in distribution and cause significant citrus production losses in the high rainfall subtropics, including the first and second largest citrus production areas in the Chhindwara district of Madhya Pradesh, India. Losses due to Phytophthora spp. may occur in seedbeds from damping-off; in nurseries from foot rot and root rot; in groves from foot rot, fibrous root rot, brown rot of fruit, and from further spread of the pathogen to adjacent fruit in packing boxes. This is one of several well-known gumming diseases of citrus. Gum formation on the trunk or branches is a characteristic symptom. Gum exudes from blisters containing gum pockets, usually located on the trunk. The main symptom of citrus gummosis is oozing of gum from the affected parts on the trunk. Infected bark remains firm with small, longitudinal cracks through which abundant amber-colored gum is exuded. During the summer, gum deposits dry and stick to the 
bark, making the symptoms of gummosis very noticeable. The wood beneath the blister shows a pink-orange color. Several factors such as freeze damage, high water table and salt accumulation contribute to the disease. Gummosis is believed to be a condition of weak and injured trees and is reported to be infectious.

This also known as brown rot gummosis is caused by one or more species of the fungus Phytophthora. This disease can affect the root system, the trunk below and above ground, branches, leaves, blossoms and fruit. It is especially troublesome during prolonged rainy periods. Trees with the bud union beneath or close to the soil and trees in poorly-drained locations are highly susceptible.

Foot rot becomes a more serious problem under unusual conditions such as those that occur following hurricanes. Healing is slower if infection occurs below ground level. The fungus may wet soils. This infection results in poor health of the tree, a thin canopy, failure to make new growth and poor fruit production. Phytophthora spp. also may attack nursery stock and young orchard trees during rainy weather. Examination of the crowns of infected trees shows symptoms similar to those described for older trees.

Phytophthora foot rot can best be controlled by preventative practices, including use of resistant rootstock and planting in welldrained land. Sour orange is the most resistant rootstock for this disease.

Phytophthora fungi are present in almost all citrus orchards. Under moist conditions, the fungi produce large numbers of motile zoospores, which are splashed onto the tree trunks. The Phytophthora species causing gummosis develop rapidly under moist, cool conditions.

\section{Materials and Methods}

The following Material and method were used in the present investigation entitled "Use of Suitable Chemical for the control of Gummosis caused by Phytophthora sp. on Nagpur Mandarin in Satpura Plateau of Madhya Pradesh". The experiments were carried out in the J. N. Krishi Vishwa Vidyalaya, Jabalpur (M.P.) Zonal Agricultural Research Station Mohagon Hawali Farm at Sausar Block of Chhindwara District of Madhya Pradesh. The fungicidal paste was applied on the main trunk up to 4 feet height with the help of locally made brush Kunchi. In control no paste was used. Application of paste on the trunk started from Month of August till December 2015. Total four applications were at 30 days interval and lesion size was recorded.

\section{Results and Discussion}

The experiment was conducted under field condition in chemical were the viz. Bordeaux paste (amend with mustard oil $1.0 \%$ ), Bordeaux paste (amend with mustard oil $0.5 \%$ ), Fytolon (amend with mustard oil $0.3 \%$ ), Fytolon (amend with mustard oil $0.8 \%$ ), Chaubatia paste (amend with mustard oil $1.0 \%$ ) were applications on tree trunk along with an un-amended control.

The observation was recorded. Results presented in table 1 indicate that development of the lesion stared from September. Inhibition in the development of lesion was recorded as compared to check where no paste was used. In case of Bordeaux paste 1 percent only $0.8 \mathrm{~cm}$ increase was recorded during September to December respectively $2.1 \mathrm{~cm}, 2.9 \mathrm{~cm}$ (Fig. 1). 
Table.1 Influence of the fungicidal treatment on the development of the lesion size on the main trunk of Nagpur Mandarin plant at Village Mohagaon Hawali Sausar

\begin{tabular}{|c|c|c|c|c|c|c|c|}
\hline \multirow[t]{2}{*}{ Treatment } & \multirow{2}{*}{$\begin{array}{c}\text { Common } \\
\text { Name }\end{array}$} & \multirow{2}{*}{$\begin{array}{c}\text { Percent / } \\
\text { Concentration }\end{array}$} & \multicolumn{4}{|c|}{ Development and size of the lesion $(\mathrm{cm})$} & \multirow{2}{*}{$\begin{array}{c}\text { Percent } \\
\text { development of } \\
\text { the lesion }\end{array}$} \\
\hline & & & $\begin{array}{c}\text { August / } \\
\text { September }\end{array}$ & $\begin{array}{c}\text { September / } \\
\text { October }\end{array}$ & $\begin{array}{l}\text { October/ } \\
\text { November }\end{array}$ & $\begin{array}{l}\text { November/ } \\
\text { December }\end{array}$ & \\
\hline $\begin{array}{c}\text { Copper Sulphate } \\
\text { Preparation } \\
\text { (Amended with mustard } \\
\text { oil } 5 \% \text { ) }\end{array}$ & Bordeaux Paste & $1 \%$ & 2.1 & 2.6 & 2.8 & 2.9 & 38.00 \\
\hline $\begin{array}{c}\text { Copper Sulphate } \\
\text { Preparation } \\
\text { (Amended with mustard } \\
\text { oil } 5 \% \text { ) }\end{array}$ & Bordeaux Paste & $1 \%$ & 2.4 & 2.4 & 3.5 & 3.6 & 45.80 \\
\hline $\begin{array}{c}\text { Copper oxychloride } \\
\text { Preparation } \\
\text { (amended with mustard } \\
\text { oil) }\end{array}$ & Fytolon & $\begin{array}{c}0 \\
.3 \%\end{array}$ & 3.0 & 3.0 & 3.9 & 4.6 & 53.33 \\
\hline $\begin{array}{l}\text { Copper oxychloride } \\
\text { Preparation }\end{array}$ & Fytolon & $0.3 \%$ & 3.1 & 4.5 & 4.9 & 5.2 & 67.74 \\
\hline $\begin{array}{l}\text { Copper carbonate } \\
\text { Preparation }\end{array}$ & Chaubatia Paste & $1 \%$ & 3.1 & 3.6 & 3.9 & 4.7 & 45.16 \\
\hline No Chemical & Control & $0 \%$ & 3.5 & 4.3 & 7.2 & 7.5 & 114.28 \\
\hline
\end{tabular}


Fig.1 Development and size of the lesion $(\mathrm{cm})$ on the main trunk of Nagpur Mandarin Plant

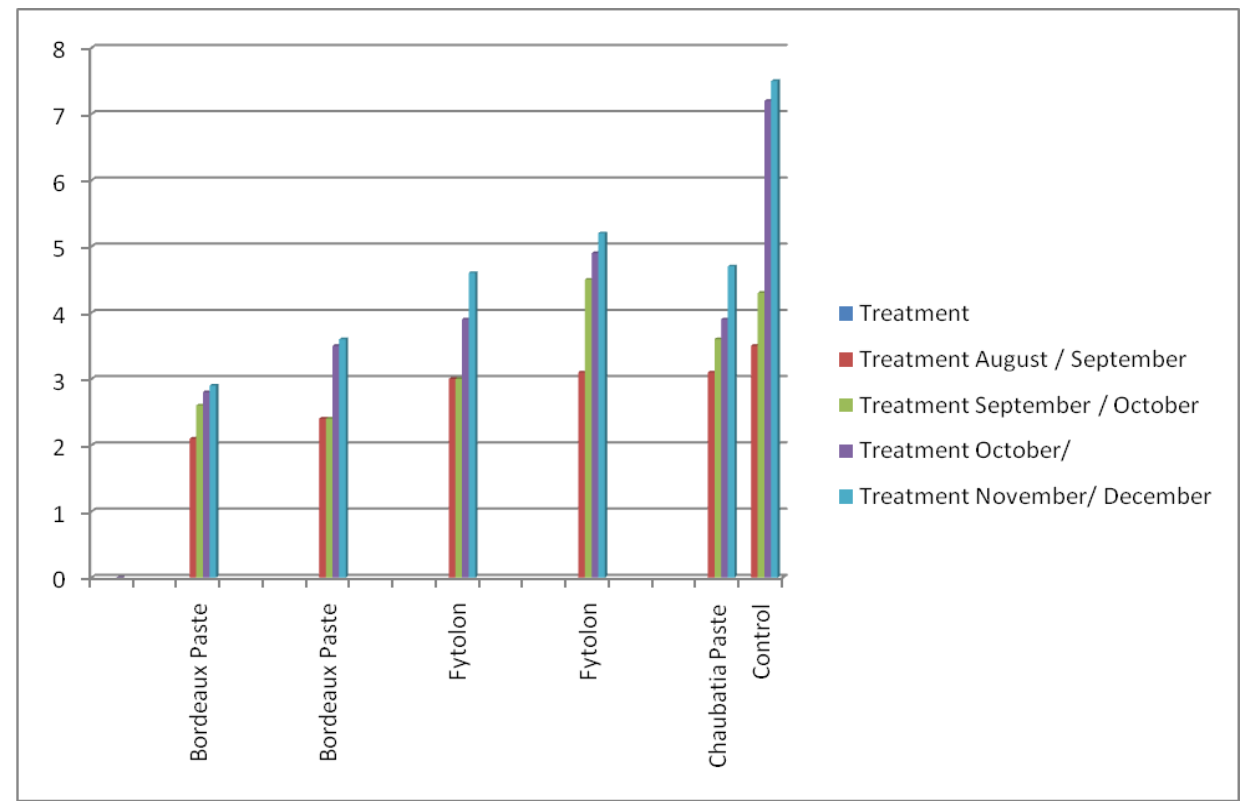

While in trees pasted with Bordeaux paste 0.5 percent it was $1.1 \mathrm{~cm}$ followed by $1.6 \mathrm{~cm}$ in fytolon and Chaubatia paste and $2.1 \mathrm{~cm}$ in Fytolon 0.3 percent with mustard oil as compared to $4.0 \mathrm{~cm}$ in check. Bordeaux paste 1.0 percent amended with mustard oil was most effective. The disease development was maximum during September and November 2015.

The lack of increase in productivity of citrus trees at sites in response to the increased gummosis densities brought about by fungicide treatment is difficult to explain.

Fungicide treatment significantly reduced populations of gummosis with the untreated control. But the benefits of treatment were not great in most cases.

In conclusion, the present study indicates that Development of the lesion stared from September. Inhibition in the development of lesion was recorded as compared to check where no paste was used. Bordeaux paste 1.0 percent amended with mustard oil was most effective.

\section{Acknowledgement}

We thank JNKVV, Zonal agriculture Research Station Chhindwara (MP) for supporting the research through Technology Mission on Citrus project.

\section{References}

Adl, S.M., A.G.B. Simpson, M.A. Farmer et $a l$., The new higher level classification of eukaryotes with 244 emphasis on the taxonomy 305 of protists, Journal of Eukaryotic Microbiology, vol. 52, no. 5, pp. 99- 245 451, 2005. 246

Ali-Shtayeh, M. S., and J.D. MacDonald, Occurrence of Phytophthora species in irrigation water in the 247 Nablus area (West Bank of Jordan), Phytopathologia Mediterranea, vol. 30, no. 3, pp. 143150, 1991. 248

Ann P-J, Ko W-H, Su H-J. 2004. Interaction between Likubin bacterium and Phytophthora parasitica in citrus hosts. Eur J Plant Path. 110: 1-6.

Ann, P.J., and W.H. Ko, An asexual variant of Phytophthora insolita, Canadian 
Journal of 251 Microbiology, vol. 40, no. 10, pp. 810-815, 1994. 252

Ann, P.J., and W.H. Ko, Phytophthora insolita, a new species from Taiwan, Mycologia, vol. 72, no. 249 6, pp. 1180$1185,1980.250$

Bowman KD, Albrecht U, McCullum G. 2008. Comparison of three new rootstocks from USDA: US- 802, US812, US897. Proceedings of the International Society of Citriculture from the 11th Citrus Congress; Wuhan, China. China Agriculture Press. p. 198199.

Bowman KD, Graham JH, Adair Jr RC. 2003. Young tree growth in a flatwoods rootstock trial with Diaprepes weevil and Phytophthora diseases. Proc Fla State Hort Soc. 116:249-251.

Bright DB, Irey MS, Baucum LE, Graham JH. 2004. Soil, rootstock and climatic factors affect populations of Phytophthora nicotianae in south Florida citrus plantings. Proc Fla State Hort Soc. 117:167-173.

Chang, H.S.,1988. Phytophthora species associated with strawberry fruit rot in Taiwan, Botanical Bulletin 253 of Academia Sinica, vol. 29, no.1, pp. 6167, 254.

Coleman B. 1993. Recent studies address fungicide resistance. Citrus Ind. 74(10):40-41.

Cooke, D.E.L., et al., A molecular phylogeny of Phytophthora and related Oomycetes, Fungal 255 Genetics and Biology, vol. 30, no. 1, pp. 17-32, 2000. 256

Cooke, D.E.L., et al., Identification of Phytophthora species on the basis of restriction enzyme 257 fragment analysis of the internal transcribed spacer regions of ribosomal RNA, EPPO Bulletin, vol. 258 30, no.3-4, pp. 519-523, 2000. 259

Das, A.K., A. Kumar, S.G. Nerkar and S.S.
Bawage, First report of Phytophthora insolita from India, 263 Australasian Plant Disease Notes, vol. 7, no. 1, pp. 131-132, 2012. 264

Das, A.K., S.G. Nerkar, S.S. Bawage and A. Kumar, First report of Phytophthora lacustris from 292 India, Journal of Plant Pathology, vol 95, no.2, pp. 447452, 2013.

Das, A.K., A. Kumar, A.A. Ingle, S.G. Nerkar, Molecular identification of Phytophthora spp. causing 260 citrus decline in Vidarbha region of Maharashtra, Indian Phytopathology, vol. 64, no., pp. 342-345, 261 2011. 262

Dick, M.A., K. Dobbie, D.E.L. Cooke and C.M. Brasier, Phytophthora captiosa sp. nov. And $P$. fallax 265 sp. nov. Causing crown dieback of Eucalyptus in New Zealand, Mycological Research, vol. 110, no. 266 4, pp. 393-404, 2006. 267

El-Borai FE, Duncan LW, Graham JH. 2002. Infection of citrus roots by Tylenchulus semipenetrans reduces root infection by Phytophthora nicotianae.

Erwin, D.C., and O.K. Ribeiro, Phytophthora diseases worldwide, APS, St. paul, Minnesota, 1996. 268

Feichtenberger E. 1997. Effect of systemic fungicide applications on growth responses and fruit yields of sweet orange trees in Phytophthora infested soil. Proc Int Soc Citrus Nurserymen. 5: 267-279.

Feichtenberger E. 2000. Manejo integrado das principais doenças dos citros no Brasil. Fitopatol Bras. 25 Suppl: 288-295.

Feichtenberger E. 2001. Doenças incitadas por Phytophthora em citros. In: Luz EDMN, Matsuoka K, Santos AF, Bezerra JL, editors. Doenças causadas por Phytophthora no Brasil. Campinas. Livraria Rural. p. 283-342.

Graham J, Johnson E, Morgan K. 2014. What growers need to know about bicarbonates and root health? Citrus 
Ind. 95(1):6-9.

Graham JH, Johnson EG, Gottwald TR, Irey MS. 2013. Presymptomatic fibrous root decline in citrus trees caused by huanglongbing and potential interaction with Phytophthora spp. Plant Dis. 97:1195-1199.

Ho, H.H., H.C. Zeng and F.C. Zheng, Phytophthora insolita on Hainan Island, Botanical Bulletin of 269 Academia Sinica, vol. 43, no. 3, pp. 227-230, 2002. 10270

Kaosiri, T., G.A. Zentmyer and D.C. Erwin, Oospore morphology and germination in the 271 Phytophthora palmivora complex from Cacao, Mycologia, vol. 72, no.5, pp. 888-907, 1980. 272.

Kong, P., B.M. Tyler, P.A. Richardson et al., Zoospore interspecific signaling promotes plant infection 275 by Phytophthora, BMC Microbiology, vol. 10, pp. 313, 2010. 276

Kroon, L.P., et al., Phylogenetic analysis of Phytophthora species based on mitochondrial and nuclear 277 DNA sequences, Fungal Genetics and Biology, vol. 41, no. 8, pp. 766-782, 2004. 278

Martin, F., Phylogenetic relationships among some Pythium species inferred from sequence analysis of 279 the mitochondrially encoded cytochrome oxidase II gene, Mycologia, vol. 92, no. 4, pp. 711-727, 280 2000. 281

Naqvi, S.A.M.H. 2004.Diagnosis and management of certain important fungal diseases of citrus, In 282 Diseases of fruits and vegetables: diagnosis and management, S.A.M.H. Naqvi, Eds., vol 1, pp. 247- 283 290, Kluwer Academic, Dordrecht, Boston, London, 284 .

Naqvi, S.A.M.H. 2006. Distribution of Citrus Phytophthora spp. and mating types pathogenic to citrus in 285 Central India, Journal of Mycology and Plant Pathology, vol. 36, no. 1, pp. 44-48, 286.

Tamura, K., et al., MEGA5: Molecular evolutionary genetics analysis using maximum likelihood, 287 evolutionary distance, and maximum parsimony methods, Molecular Biology and Evolution, vol. 28, 288 no. 10, pp. 2731-2739, 2011. 289

Testa, A., et al., First report of Phytophthora insolita and $P$. inflata on rhododendron in Ohio, Plant 290 Disease, vol. 89, no. 10, pp. 1128-1128, 2005. 291

\section{How to cite this article:}

Bhupendra Thakre, Uttam Soni and Gour, C.L. 2017. Use of Suitable Fungicides for the Control of Gummosis Caused By (Phytophthora sp.) On Nagpur Mandarin in Satpura Plateau of Madhya Pradesh. Int.J.Curr.Microbiol.App.Sci. 6(7): 2395-2400.

doi: https://doi.org/10.20546/ijcmas.2017.607.341 